\title{
For the People, Against the Elites: Left versus Right-Wing Populism in Greece and Turkey
}

\author{
loannis N. Grigoriadis \\ Bilkent University
}

\begin{abstract}
While the rise of populism has been a global trend in recent years, it has been prevalent in Greece and Turkey for longer, leaving a strong imprint on the politics of both countries. Leftwing populism has become one of the constitutive elements of the Greek political party system since the collapse of the 1967-1974 military regime. The 2009 outbreak of the Greek economic crisis set the stage for the radicalization of Greek politics through the rise of extremist far-right and far-left populist parties that professed populist agendas of different hues. Such populists accused old-party personnel of being members of a "treacherous elite" that sacrificed Greek national interests against foreign powers. The 2011 "indignados" movement is key for the better understanding of the social dynamics that facilitated the rise of the unusual SYRIZA-ANEL coalition government. Debates on Greek constitutional reform also highlighted the relevance of populism, especially as the SYRIZA-ANEL government sought topics to resonate with its disenchanted voters. On the other hand, a right-wing populist rhetoric has been one of the key instruments for the rise of Turkish political Islam and the establishment of the AKP hegemony in Turkey. Establishing a Kulturkampf-based narrative about the "secularist, 'white-Turk' elites" versus the "conservative, 'black-Turk' people" was of great political significance. The constitutional reform process proved again crucial for manifesting the relevance of populism in Turkish political discourse. This article explores the circumstances under which left- and right-wing populism have emerged into a dominant feature of Greek and Turkish politics. It also discusses the decreasing relevance of the established leftright political divide in party politics and suggests alternative classifications.
\end{abstract}

\section{KEYWORDS}

AKP; constitution; elite; Erdoğan; Greece; indignados; left; populism; right; SYRIZA; Tsipras; Turkey

\section{Introduction}

Populism was on the rise in both Greece and Turkey of the 2010s. The Greek economic crisis set the stage for the radicalization of Greek politics through the upsurge of populist parties. As left-wing populism had been familiar to Greek party politics since the fall of the military regime in 1974, its resurgence proved relatively easy. Populists accused old-party personnel of being

CONTACT loannis N. Grigoriadis ioannis@bilkent.edu.tr $\Theta$ Department of Political Science and Public Administration, Bilkent University, Bilkent, Ankara, Turkey. 
members of a "treacherous elite" that sacrificed Greek national interests to foreign powers. The 2011 "indignados" movement is key for the better understanding of the social dynamics that confirmed the prevalence of populism across the Greek political spectrum. It brought together far-left and far-right movements and facilitated the rise of the unusual and seemingly incompatible Synaspismós Rizospastikís Aristerás (Coalition of the Radical Left, or SYRIZA) and the right-wing Anexartitoi Ellines (Independent Greeks, or ANEL) coalition government. Debates on Greek constitutional reform also highlighted the relevance of populism, especially as the SYRIZA-ANEL government was forced to follow the economic policy it had long chastised to come to power and sought ways to appease its disenchanted voter base. On the other side of the Aegean, a right-wing populist rhetoric has been one of the key instruments for the establishment of the Adalet ve Kalkınma Partisi (Justice and Development Party, or AKP) hegemony in Turkey since its rise to power in 2002. Establishing a Kulturkampfbased narrative about the "secularist, 'white-Turk' elites" versus the "conservative, 'black-Turk' people" proved to be crucial for the establishment of AKP hegemony. The secularist elites that governed republican Turkey and were represented by the Cumhuriyet Halk Partisi (Republican People's Party, or CHP) had no legitimacy with the people, who were genuinely represented by the AKP and its leader Recep Tayyip Erdoğan. Turkey's constitutional reform and the introduction of a strong presidential system following the April 2017 constitutional referendum reconfirmed the relevance of rightwing populism in Turkish political discourse and the significance of constitutional reform as an instrument for the party's political hegemony.

This study aims to explore the circumstances under which left- and right-wing populism have emerged into a dominant feature of Greek and Turkish politics in the 2010s. While the varieties of Greek and Turkish populism have considerably diverged, there nevertheless are strong similarities that render a comparison of the two both meaningful and important. This study argues that populism has risen to become such an influential feature of Greek and Turkish politics because of the historic conditions of modernization in both countries. The emergence of deep social divides along religious, ideological, or cultural lines have made both countries susceptible to the influence of populist rhetoric. Constitutional politics has become one of the main fields where populists have chosen to stage their political confrontation with their opponents. For the purpose of this article, populism is understood as a superficial political ideology that can be combined with left- or right-wing preferences on issues, such as international relations, economic freedom, and individual autonomy. ${ }^{1}$ This means that depending on the political, economic, and social conditions intrinsic to each country, left- or right-wing

${ }^{1}$ Jan-Werner Muller, What Is Populism? (Philadelphia: University of Pennsylvania Press, 2016), 9-11; and Cas Mudde and Cristóbal Rovira Kaltwasser, Populism: A Very Short Introduction (Oxford; New York, NY: Oxford University Press, 2017), 5-6. 
varieties of populism would be likely to thrive and dominate the public sphere. The prevalence of ideological polarization along the left-right axis has often occluded analysts from recognizing crucial similarities between left- and rightwing populist movements.

This interpretation argues that studying the Greek and Turkish cases provides valuable insights about the similarities between left- and right-wing populist movements. In particular, the alliance between the left-wing, populist SYRIZA coalition and the far-right, populist ANEL poses an interesting study case. The smooth cooperation of these two seemingly unlikely partners points to the fact that affinities between left- and right-wing populism are stronger than originally thought and that the relevance of the established left-right political divide is problematic. Moreover, studying the Greek case raises doubts concerning the view that left-wing populism is an essentially positive force. ${ }^{2}$ The alliance between SYRIZA and ANEL further provides a valuable analytical tool for the evaluation of left- and right-wing populism in Western democracies. Studying the Turkish case also proves very useful in terms of gaining a better understanding of the rise of populist movements in states where democratic backsliding has been observed and hybrid regimes have succeeded procedural democracies.

\section{Greece and the prevalence of left-wing populism}

Greek populism has thrived on the deep ideological and political divisions that shaped Greek politics throughout the twentieth century. ${ }^{3}$ Already in 1915, a major political confrontation between the two heads of the Greek executive King Constantine I and Prime Minister Eleftherios Venizelos, resulted in the collapse of the Greek constitution and the temporary division of the Greek state under two different governments. ${ }^{4}$ This triggered what is known as the "National Schism (Ethnikos Dichasmos)", a political rift within the Greek society between Venizelos's supporters (Venizelists) and opponents (Antivenizelists) and which survived until the end of the Second World War. Soon thereafter, the 1946-1949 Greek Civil War erupted between proWestern government forces and left-wing insurgents who sought to establish a Communist regime in Greece, which ended with a victory of the former but not without first ruining the war-ravaged country. Greece's democracy subsequently suffered from major deficiencies throughout the 1950s and 1960s.

\footnotetext{
${ }^{2}$ Ernesto Laclau, On Populist Reason (London \& New York: Verso, 2005), 157-71; Chantal Mouffe, "The 'End of Politics' and the Challenge of Right-wing Populism," in Populism and the Mirror of Democracy, ed. Francisco Panizza (London \& New York: Verso, 2005), 72-98. The intolerance of some left-wing populist movements in Latin America and beyond to pluralism is indicative in that respect.

${ }^{3}$ On the deeper roots of Greece's social divisions, see Nikiforos Diamandouros, Cultural Dualism and Political Change in Post-authoritarian Greece (Madrid: Instituto Juan March de Estudios e Investigaciones, 1994).

${ }^{4}$ John S. Koliopoulos and Thanos M. Veremis, Modern Greece: A History since 1821 (Chichester: WileyBlackwell, 2010), 77-86. While the dispute reflected ongoing transformations in Greek politics and society, it referred to Greece's orientation during the First World War, namely whether it should join the Entente or remain neutral.
} 
The right-wing military coup of April 21, 1967, proved a watershed event in Greek history, and resulted in the suspension of the country's constitution and seven years of authoritarian rule. Under the leadership of Georgios Papadopoulos (1967-1973) and Dimitrios Ioannidis (1973-1974), the military regime employed populist rhetoric in its effort to justify its decision not to return to the barracks following the removal of the "inept civilian government" but to rule the country for an indefinite period of time. The colonels contended that corrupt political and economic elites had brought Greece to the brink of disaster, so that military intervention had been the only way to defend the "people's interests." Thus, the military identified itself with the people, and sought to legitimize its continued control of the country. It was only on July 24, 1974, at the onset of the Greek-instigated military coup in Cyprus and the subsequent Turkish invasion of the island, that the junta collapsed.

Following the Cyprus fiasco, Greece returned to civilian rule with the creation of a national unity government led by Konstantinos Karamanlis. While Karamanlis and his center-right New Democracy party comfortably won the ensuing November 17, 1974 parliamentary elections and his party ruled Greece for the remainder of the decade, they would soon be challenged from the left by the Panhellenic Socialist Movement (PASOK), which had been founded in September 1974 by Andreas Papandreou. ${ }^{5}$ Papandreou skillfully employed populism as well as left-wing rhetoric in his rise to a hegemonic position in Greek politics. ${ }^{6}$ Papandreou's political strategy bore fruit, as PASOK rose from the periphery to become the dominant political party in Greece in the 1980s. Papandreou and PASOK would leave a heavy imprint on Greek politics and society. Capitalizing on growing anti-American sentiments and the ostracization of left-wing citizens from state positions that had occurred between 1949 and 1974, Papandreou engaged in a harsh critique of the Greek establishment, of which he was in fact a prominent member. He argued that center-right governments did not represent the genuine interests of the Greek people, but only those of the "corrupt elites." Hence, democracy had not really been restored in 1974 with the return of civilian rule in Papandreou's view. ${ }^{7}$

Thus, it was not until PASOK's landslide electoral victory on October 18, 1981 that "true democracy" was reestablished in Greece. Papandreou showed himself

\footnotetext{
${ }^{5}$ Takis S. Pappas, "Populist Democracies: Post-authoritarian Greece and Post-Communist Hungary," Government and Opposition 49, no. 1 (2014): 9-10; and Takis S. Pappas, Populism and Crisis Politics in Greece (New York: Palgrave Macmillan, 2014), 21-26. Papandreou was the son of Prime Minister George Papandreou, who had been leader of Enossis Kentrou (Center Union) in the 1960s. Although he entered Greek politics as a scion in the early 1960s, in the wake of the collapse of the military regime, he avoided rejoining the centrist party founded by his father. Instead, he established PASOK and moved it to the left, capitalizing on the resentment left from the oppression of Greece's left and center-left during the post-Second World War era.

${ }^{6}$ Yannis Stavrakakis and Giorgos Katsambekis, "Left-wing Populism in the European Periphery: The Case of SYRIZA," Journal of Political Ideologies 19, no. 2 (2014): 124-26, https://doi.org/10.1080/13569317.2014. 909266.

${ }^{7}$ Following the collapse of the military regime, the Karamanlis government organized free parliamentary elections on November 17, 1974 and a referendum on the future of Greek monarchy on December 8, 1974. It also introduced a new republican constitution, which was promulgated on June 11, 1975.
} 
keen to maintain such populist rhetoric while in power - especially given the fact that his government failed to deliver most of the radical promises he had made on his way to power. Moreover, he implied that while PASOK was the leading party in the government, it still did not have real power because of the continued influence of Greek elites and Karamanlis, who had relinquished the office of prime minister to be elected president of the Hellenic Republic in May 1980. While the cohabitation of Karamanlis and Papandreou proved more harmonious than one might have expected, it did not last. A crisis occurred when, contrary to expectations, Papandreou announced on March 9, 1985 that PASOK would not support the reelection of Karamanlis. The Prime Minister contended that the existence of a strong president curbed the will of the people, and accordingly announced plans for a far-reaching constitutional amendment that would strip the presidency of much of the powers that balanced those of the prime minister. Winning the ensuing June 1985 parliamentary elections confirmed popular support for Papandreou and led to the successful amending of the constitution. Papandreou would serve as prime minister until June 1989, and again lead Greece between October 1993 and January 1996 when ill health led to his resignation.

Under Andreas Papandreou's successors, Konstantinos Simitis (19962004) and George Papandreou (2009-2011), PASOK attempted at times to distance itself from its founding populist discourse. Nonetheless, this change by no means meant that the appeal of populism in Greek politics was in decline. In fact, other public figures on the right adopted populist tactics. A prime example of this switch was Archbishop Christodoulos who polarized Greek society by vehemently opposing the removal of reference to religious affiliation on Greek identity cards, a secularization measure introduced by the Simitis administration. ${ }^{8}$ New Democracy leader and Prime Minister (2004-2009) Kostas Karamanlis, too, often employed populist tactics. To wit, Karamanlis successfully presented Simitis's government as representative of the country's economic elites and his center-right party as the true representative of people's interests.

The coming of the severe Greek economic crisis in fall $2009^{9}$ at the outset of the global financial turmoil established suitable conditions for the resurgence of populism, ${ }^{10}$ as the economic and social turmoil delegitimized the old political parties. ${ }^{11}$ While new populist parties emerged on the far left and right margins of the Greek political spectrum, SYRIZA, in particular,

\footnotetext{
${ }^{8}$ Yannis Stavrakakis, “Antinomies of Formalism: Laclau's Theory of Populism and the Lessons from Religious Populism in Greece," Journal of Political Ideologies 9, no. 3 (2004): 258-62. This was one of the fiercest political confrontations of the early 2000s, which was won by the Simitis administration.

${ }^{9}$ George Pagoulatos and Christos Triantopoulos, "The Return of the Greek Patient: Greece and the 2008 Global Financial Crisis," South European Society and Politics 14, no. 1 (2009): 35-37.

${ }^{10}$ Pappas, Populism and Crisis Politics in Greece, 71-77.

${ }^{11}$ Ioannis N Grigoriadis, “Greek Tragedy,” World Policy Journal 28, no. 2 (2011): 105-08; and Sofia Vasilopoulou and Daphne Halikiopoulou, “Greek Politics: Economic Crisis or Crisis of Democracy?” World Affairs 178, no. 3 (2015): 14-15, www.jstor.org/stable/24888110.
} 
capitalized on the left-wing populist canon of Greek politics to rise meteorically from the periphery of Greek politics and to come to power. ${ }^{12}$ In many respects, SYRIZA followed in the footsteps of early PASOK. Alexis Tsipras, the party leader, aspired to emulate Andreas Papandreou and his radical populism of the 1970s in his rhetoric, style, and tactics. He squarely blamed the economic crisis on the European Union and international markets, and thus reversed the actual causal direction of developments related to the Greece's predicament. In Tsipras's view, it was not the economic crisis that led to the bailout agreements and the concomitant austerity measures, but the opposite was true-the country's hardships had been brought about by austerity policies imposed by outside forces. Hence, the solution for the economic crisis was simple. Tsipras and SYRIZA presented the abolition of the memorandum agreements as the way to begin to bring an end to Greek economic and social woes and ultimately embark on the country's economic recovery.

\section{The Greek indignados and the SYRIZA-ANEL government}

Inspired by the indignados (Spanish "outraged") movement, which protested against austerity measures imposed by the Spanish government on May 15, 2011, the Greek indignados started gathering ten days later at Syntagma Square, Athens's central public space, declaring their outrage against the crisis and the political elites they blamed for bringing the country to its knees. The crowd was very diverse, soon the square was divided into an "upper square sector" where far-right-wing demonstrators would gather and a "lower square sector," preferred by their far-left counterparts.

Despite apparent differences, it soon became clear that there were common threads among the protestors including a sense of the victimization of Greece and its people, a belief in the country's exceptionalism, contempt for parliamentary democracy, and a miserabilistic view of the country as well as its prospects. In their view, Greece was unique in its history and institutions and was not responsible for its predicament; in fact, it was a victim of globalization and capital markets. ${ }^{13}$ Their view of the PASOK government remained extremely negative, despite its determined effort to prevent a default. ${ }^{14}$ Their remedy was clear: Greece had to abandon austerity programs; cut off its relations with the troika of its creditors, i.e., the European

\footnotetext{
${ }^{12}$ Michalis Spourdalakis, “The Miraculous Rise of the 'Phenomenon SYRIZA," International Critical Thought 4, no. 3 (2014): 354-60, https://doi.org/10.1080/21598282.2014.931022; Myrto Tsakatika, "SYRIZA's Electoral Rise in Greece: Protest, Trust and the Art of Political Manipulation," South European Society and Politics 21, no. 4 (2016): 522-25, https://doi.org/10.1080/13608746.2016.1239671; and Stavrakakis and Katsambekis, "Left-wing Populism in the European Periphery," 126-33.

${ }^{13}$ Sofia Vasilopoulou, Daphne Halikiopoulou, and Theofanis Exadaktylos, "Greece in Crisis: Austerity, Populism and the Politics of Blame," Journal of Common Market Studies 52, no. 2 (2014): 388-90.

${ }^{14}$ George Pagoulatos, “Desperately Hanging on: A Euro-crisis View from Greece," European Council on Foreign Relations (2012): 1-4.
} 
Commission, the International Monetary Fund (IMF) and the European Central Bank (ECB); and lead a global struggle against such harsh and counterproductive policies. These views fit very well their perception of Greece as being a pioneer in the world-wide struggle against globalization and the domination of capitalism. Indeed, Greece represented a veritable Arcadia of anti-capitalist resistance. Foreign intellectuals and activists lent credibility to that perception, orientalizing, and exoticizing Greece in ways reminiscent of eighteenth- and nineteenth-century Philhellenism. This pessimistic and cynical understanding of the world and politics, in fact, paved the way for the ascendance of clearly antiliberal and antidemocratic political movements. ${ }^{15}$

In the elections of January 25,2015, SYRIZA gained the plurality of votes but not enough seats to form a single-party government. Its decision to choose neither a liberal nor a center-left party, such as the Potami (River), or Kinima Allagis (Change Movement, or KINAL), but ANEL as its government partner spoke volumes about the emerging reconfiguration of Greek politics. ${ }^{16}$ While the attempt of the SYRIZA-ANEL coalition to navigate between its promises and hard realities failed miserably and came at a huge cost to the Greek economy in summer 2015, ${ }^{17}$ its capitulation on matters of economic policy did not mean the end of populist tactics. Tsipras emerged as a charismatic leader, following the footsteps of Andreas Papandreou. ${ }^{18}$ Polarizing Greek public opinion on domestic policy issues, beyond the economic austerity program became a key tactic of the SYRIZA-ANEL government that wished to limit defections from its increasingly disillusioned base. Like in the 1980s, the question of the Republic's constitution served as an opportunity to promote a populist agenda. Introducing a discussion of constitutional "reforms" aimed at weakening check-and-balance mechanisms as well as the integrity of crucial institutions in the name of "direct democracy" further had the objective of perpetuating the divisions of Greek society along the lines that suited best the interests of the SYRIZA-ANEL government. Weakening the offsetting role of the judiciary and the legislative against the executive was one of the main

\footnotetext{
${ }^{15}$ Panayis Panagiotopoulos and Dimitris P. Sotiropoulos, "Introduction: Framing Greek Exoticism. History and the Current Crisis," in Political and Cultural Aspects of Greek Exoticism, eds. Panayis Panagiotopoulos and Dimitris P. Sotiropoulos (Cham, Switzerland: Springer, 2019), 1-8.

${ }^{16}$ Paris Aslanidis and Cristóbal Rovira Kaltwasser, "Dealing with Populists in Government: The SYRIZA-ANEL Coalition in Greece,” Democratization 23, no. 6 (2016): 1080-84, https://doi.org/10.1080/13510347.2016. 1154842 .

${ }^{17}$ On the cost of the SYRIZA-ANEL government negotiation with the troika, see Klaus Regling, "First Half of 2015 Cost Greece 86-200 bln Euros," Kathimerini (English Edition) (Athens), August 19, 2018, http://www. ekathimerini.com/231837/article/ekathimerini/business/regling-in-kathimerini-first-half-of-2015-cost-greece -86-200-bln-euros; and Viktoria Dendrinou and Eleni Varvitsioti, The Last Bluff: How Greece Came Face-toFace with Financial Catastrophe \& the Secret Plan for its Euro Exit (Athens: Papadopoulos, 2019). Regling has been the Chief Executive Officer of the European Financial Stability Facility and Managing Director of the European Stability Mechanism.

${ }^{18}$ Cas Mudde, SYRIZA: The Failure of the Populist Promise (Cham, Switzerland: Palgrave Pivot, 2016), 7-24; and Yannis Stavrakakis, "Populism in Power: Syriza's Challenge to Europe," Juncture 21, no. 4 (2015): 277-78, https://onlinelibrary.wiley.com/doi/abs/10.1111/j.2050-5876.2015.00817.x.
} 
features of the proposed amendments. In other words, the populists promoted a stronger majoritarian view of democracy as remedy for the ills of the Greek polity. The popularization of referenda as means to resolve domestic and foreign policy issues and the discussion of the constitutional amendment in specially designated popular bodies betrayed mistrust of representative democracy. ${ }^{19}$ Coalition members fueled dissatisfaction concerning the current state of affairs as well as the "old institutions" and channeled this discontent toward new institutional arrangements. The collapse of the SYRIZA-ANEL government in May 2019 and its resounding defeat in the early parliamentary elections of July 7, 2019 prevented the realization of the constitutional reform plans of the coalition; yet, they still maintain their relevance as a populist blueprint for the reconfiguration of Greek politics.

\section{Turkey and the prevalence of right-wing populism}

Turkey's political history in the twentieth century has also proved suitable for the nurturing of populist movements. This trend is not only due to the conditions that led to the outbreak of the 1908 Young Turk Revolution, the demise of the Ottoman Empire, the emergence of the Republic of Turkey and the Ataturk modernization program, ${ }^{20}$ but it can also be linked to the framing of key contentious issues in Kulturkampf terms. ${ }^{21}$ Indeed, modern Turkish debates bear a strong resemblance to the famous conflict of the late nineteenth century between the state and Catholic Church in imperial Prussia not to mention the confrontations between Kemalism and Islam in early republican Turkey. What differs are the terms of the confrontation. While secularists held the upper hand throughout the history of republican Turkey until 2002, it was the Islamists who eventually gained the advantage with the subsequent consolidation of the AKP power. This development provided a fertile ground for the breeding of populism, as speaking in the name of the people is a key claim of Kulturkampf activists. ${ }^{22}$

For a variety of demographic, political, and social reasons, Turkish politics have gravitated toward the right. While the military participated in a series of coups in the twentieth century, its leaders ultimately abstained from installing itself in long-lasting governments. Nevertheless, Turkish praetorians made sure to suppress left-wing political movements and tilt the balance of

\footnotetext{
${ }^{19}$ Ioannis N. Grigoriadis, Democratic Transition and the Rise of Populist Majoritarianism: Constitutional Reform in Greece and Turkey (Cham, Switzerland: Springer, 2018), 48-49.

${ }^{20}$ Erik Jan Zürcher, Turkey: A Modern History, new ed. (London: I. B. Tauris, 2004), 93-183.

${ }^{21}$ Ioannis N Grigoriadis and Theocharis N Grigoriadis, "The Political Economy of Kulturkampf: Evidence from Imperial Prussia and Republican Turkey," Constitutional Political Economy 21, no. 3 (2018): 349-54.

${ }^{22}$ Kulturkampf was about restoring the true culture of the people, however this was defined; removing any vestiges of cultures that had allegedly adulterated the original features of cultural identity was considered to be essential. On this, also see Ersin Kalaycığlu, "Kulturkampf in Turkey: The Constitutional Referendum of 12 September 2010," South European Society and Politics 17, no. 1 (2012): 6-7.
} 
the political spectrum toward the right so that the Turkish left remained weak, both institutionally and politically. Moreover, the introduction of a "Turkish-Islamic Synthesis" (Türk-İslam Sentezi-TIS) in the 1970s and its emergence as de facto official ideology of the Republic following the September 12, 1980 military coup also meant that Communism, Islamism, and Kurdish nationalism would be identified as key threats to the integrity of Turkey.

The failure of a successful leftist political movement to institutionalize itself has compounded the weakness of the Turkish left. The role of the Republican People's Party (Cumhuriyet Halk Partisi, or CHP) in this has been crucial. The CHP, which was the party of Turkey's founding father Mustafa Kemal Atatürk, attempted to reform itself from the onset of multiparty politics and eventually establish itself in the center-left (ortanin solu) of the political spectrum. Nevertheless, the party remained too attached to Turkey's state elite, and failed to represent the interests of Turkey's labor class. As urbanization and industrialization were irreversibly transforming Turkish society and led to the rise of a Turkish urban poor in the country's big cities, these social groups did not join the ranks of left-wing political movements. Instead, a Turkish brand of political Islam captured this political momentum, as identity politics along the Islamist-secularist fault line became one of the defining characteristics of Turkish politics. With the rise of Turkish political Islam since the late 1960s, and notably the September 12, 1980 military coup, which dealt a heavy blow to left-wing political organizations, the emergence of a successful, left-wing, populist movement became increasingly difficult in Turkey.

The vacuum of the populist arena was eventually filled and dominated by Islamist political parties and leaders. The first of these was the Welfare (Refah) Party under the leadership of Necmetttin Erbakan. This was followed by the rise of the Justice and Development Party (Adalet ve Kalkınma Partisi, or AKP) and its charismatic leader, Recep Tayyip Erdoğan. Under the leadership of these two parties, Turkish political Islam created its own populist narrative. As republican elites had usurped popular sovereignty for decades, Turkish Islamists considered their duty to reclaim the legacy of the Ottoman Empire, ${ }^{23}$ represent the interests of the oppressed masses, and introduce "true democracy" to Turkey. Islamist leaders did not see the West as a source of emulation or a role model, but instead as one of the forces that were facilitating the oppression of the Turkish people. While Erbakan became republican Turkey's first Islamist prime minister in June 1996, he could not challenge the dominant role of secularist elites. and succumbed to the "postmodern coup" of February 28, 1997.

\footnotetext{
${ }^{23}$ Umut Uzer, "Glorification of the Past as a Political Tool: Ottoman History in Contemporary Turkish Politics," The Journal of the Middle East and Africa 9, no. 4 (2018): 354-56, https://doi.org/10.1080/ 21520844.2018.1539063.
} 
Thus, Recep Tayyip Erdoğan, who engaged in a long, anti-establishment political campaign targeting Turkey's secularist elites, would carry the populist torch. ${ }^{24}$ The AKP leader exploited the division of the Turkish society along the lines of the Kemalist secularist elite and the Muslim conservative majority. $\mathrm{He}$ claimed to represent society's underdogs, or the "Black Turks" (Siyah Türkler), who had always been discriminated against and marginalized by the "White Turks" (Beyaz Türkler), who constituted the members of the republican elite. In the event, Erdoğan's populist message proved very powerful. ${ }^{25}$ Capitalizing on a deep political and economic crisis that ruined the appeal of mainstream political parties, his party rose to control the government in November 2002, and Erdoğan has remained the dominant figure of Turkish politics ever since. His claim was that his party brought true democracy to the country, because it represented the original values and the genuine interests of the Turkish people. In a manner typical of populist leaders who have attained power, Erdoğan insisted that he represented Turkey's underdogs almost twenty years after his rise to power. To do so he had to argue that he never really had full power, although he was the leader of the government, because someone always stood in his way. Thus, over time he has blamed the military and bureaucratic elites, the Gülen movement, the United States or the West in general for blocking his objectives, and presented them as the enemies who have obstructed his exercise of full power. It is, therefore, a democratic duty for patriotic Turkish citizens to stand by the AKP government in its various struggles against both domestic and foreign adversaries.

In the first years of AKP rule, it was the Turkish military and civil bureaucracy whom Erdoğan accused of limiting the sovereign rights of the Turkish people through their tutelary position within the Turkish state. As the military's political role diminished from 2006 onwards following the Ergenekon, Sledgehammer (Balyoz), and Memorandum (Andıç) investigations and the AKP's survival in the 2008 closure case brought before the Constitutional Court, new enemies emerged in the third and fourth term of the AKP administration. Following the breakdown of relations with his erstwhile ally, the Gülen movement, and the 2013 Gezi demonstrations, which shook the self-confidence of the Turkish government, AKP officials identified the Gülenists, civil society organizations, and foreign powers as enemies of the Turkish people. The all-out war against the Gülen movement, who were eventually considered a terrorist organization under the name of Fethullahist Terrorist Organization (Fethullahçı Terör Örgütü, or FETÖ), led to thousands of arrests as well as purges of the bureaucracy and military. The failed coup of July 15, 2016, the organization of which authorities attribute to the Gülenists, triggered a sharp increase of purges in all state institutions, as the subsequent declaration of a state of emergency

\footnotetext{
${ }^{24}$ Şakir Dinçşahin, “A Symptomatic Analysis of the Justice and Development Party's Populism in Turkey, 2007-2010," Government and Opposition 47, no. 4 (2012): 626-39.

${ }^{25}$ On this, see Toygar Sinan Baykan, The Justice and Development Party in Turkey: Populism, Personalism, Organization (Cambridge: Cambridge University Press, 2018), 61-105.
} 
suspended constitutional guarantees for human rights and the rule of law throughout the Republic of Turkey. Moreover, AKP officials presented the unwillingness of the international community to fully endorse the official narrative about the abortive putsch and its aftermath as evidence for foreign complicity with the coup plotters. Accordingly, the government promoted the line that domestic and international forces conspired to usurp sovereignty from the hands of the Turkish people. Only due to the steadfast resistance of the people and the resolute leadership of the AKP did their plans fail. ${ }^{26}$

Beyond the official accounts concerning enemies near and far, another key element for the promotion of President Erdoğan's populist agenda related to the issue of constitutional reform. Constitutional law experts had identified the need for a drastic amendment of the Turkish constitution, which they considered to be a vestige of Turkey's authoritarian past. While the debate on this question in the early years of the AKP administration focused on introducing a new, liberal democratic constitution, it later shifted in a different direction, following the AKP's continuation in power for a third term. The new plan was to create a constitution that would pave the way for the Republic's transition from a parliamentary to a presidential system. The idea was to weaken or lift checkand-balance mechanisms in favor of allowing for a stronger executive. ${ }^{27}$ Crafters of the new fundamental law envisioned the abolition of the office of the prime minister with the creation of the new order. Buoyed by the favorable political environment in the aftermath of the abortive July 15, 2016 coup, Erdoğan exploited the opportunity to present his desired constitutional reform to the people in the form of a referendum. The vote, which was held on April 16, 2017, produced a thin majority in favor of the new constitution and confirmed Erdoğan's hegemonic position. The consolidation of majoritarian features as part of the Turkish political system gave an indispensable role to the president. ${ }^{28}$ In addition, this decisive, swift turn toward majoritarianism led to further discussions about Turkey's democratic backsliding. $^{29}$

\footnotetext{
${ }^{26}$ The 2013 Gezi demonstrations proved a critical juncture in that respect, as they disproved the claim that the AKP could claim a monopoly on the people and social mobilization. On this, see Hayriye Özen, "An Unfinished Grassroots Populism: The Gezi Park Protests in Turkey and Their Aftermath," South European Society and Politics 20, no. 4 (2015): 537-44.

${ }^{27}$ Orçun Selçuk, "Strong Presidents and Weak Institutions: Populism in Turkey, Venezuela and Ecuador," Southeast European and Black Sea Studies 16, no. 4 (2016): 575-78.

${ }^{28}$ Grigoriadis, Democratic Transition and the Rise of Populist Majoritarianism: Constitutional Reform in Greece and Turkey, 63-67.

${ }^{29}$ Meltem Müftüler-Baç and E. Fuat Keyman, “Turkey's Unconsolidated Democracy: The Nexus between Democratisation and Majoritarianism in Turkey," in Global Turkey in Europe III: Democracy, Trade, and the Kurdish Question in Turkey-EU Relations, eds. Senem Aydın-Düzgit et al. (Rome: IAI \& Edizioni Nuova Cultura, 2015), 122-27; Ergun Özbudun, "Problems of Rule of Law and Horizontal Accountability in Turkey: Defective Democracy or Competitive Authoritarianism?" in Democratic Consolidation in Turkey: Micro and Macro Challenges, eds. Cengiz Erisen and Paul Kubicek (Oxford \& New York: Routledge, 2016), 42-44; Berk Esen and Sebnem Gumuscu, "Rising Competitive Authoritarianism in Turkey," Third World Quarterly 37, no. 9 (2016): 1582-86; and Antonino Castaldo, "Populism and Competitive Authoritarianism in Turkey," Southeast European and Black Sea Studies 18, no. 4 (2018): 478-81. Turkey was often considered as a case where a hybrid regime between consolidated democracy and authoritarianism gradually emerged.
} 
The relevance of populism as an analytical tool of Turkish politics was confirmed yet again in the June 24, 2018 presidential elections. ${ }^{30}$ President Erdoğan ran a successful campaign by juxtaposing himself as the representative of the people as opposed to the protegés of domestic elites and international actors. He adopted the role of the "protector of the unprotected" and the "defender of the oppressed." Victimhood featured high in his electoral campaign.

Here one should recognize that Erdoğan's opponents employed similar populist tactics, as they contested the election. For example, the CHP presidential candidate Muharrem Ince refuted the accusation that he and his party represented the elites. On the contrary, Ince argued that it was he who represented the people who had been marginalized after sixteen years of AKP rule. Such efforts to appeal to the parts of Turkish voters alienated from the CHP, nonetheless, failed to deliver tangible results. Meanwhile, the candidate of the Peoples' Democratic Party (Halklarm Demokratik Partisi, or HDP) Selahattin Demirtaş ${ }^{31}$ also employed populist themes in his campaign, highlighting that his candidacy represented the true interests of the people.

It is worth pointing out that it has been contended that there were at this time three distinct types of populism in Turkey, and that practically all major political parties employed some variety of populism. ${ }^{32}$ That this is genuine populism is particularly hard to defend; however, not only in light of the inability of the HDP to address the whole of Turkish society but also because of the failure of $\mathrm{CHP}$ to escape from its elitist sociopolitical roots. ${ }^{33}$ In particular, Erdoğan's campaign against the HDP was easier, given that in the eyes of Turkish public opinion the HDP remained too closely related to the Kurdish Workers' Party (PKK) terrorism, Kurdish nationalism and separatism. While in the June 2015 elections the HDP had made unprecedented inroads into the mainstream Turkish public opinion with its conciliatory and peace-oriented agenda, ${ }^{34}$ the resumption of violence between Turkish security forces and PKK insurgents in eastern and southeastern Turkey reactivated the divide between ethnic Turks and Kurds and faded its appeal to mainstream Turkish public opinion. The validity of any HDP claim to represent the whole Turkish people and not just a part of the

\footnotetext{
${ }^{30}$ Bill Park, "Populism and Islamism in Turkey," Turkish Studies 19, no. 2 (2018): 174-75.

${ }^{31}$ Demirtaş participated in the presidential election from a prison cell in Edirne, since he had been detained on spurious charges of supporting terrorism.

${ }^{32}$ Omer Tekdemir, "Left-wing Populism within Horizontal and Vertical Politics: The Case of Kurdish-led Radical Democracy in Agonistic Pluralism," Journal of Balkan and Near Eastern Studies (2018): 335-40, https://doi.org/10.1080/19448953.2018.1497756.

${ }^{33}$ The election of Ekrem İmamoğlu as Istanbul's metropolitan mayor in the double elections of March 31 and June 23, 2019 manifested that a CHP candidate could appeal to the average Turkish citizen and win a triumphant victory against the AKP candidate, Binali Yıldırım. It is noteworthy though that İmamoğlu did not succeed by adopting a populist rhetoric, but rather a conciliatory one.

${ }^{34}$ Ioannis N. Grigoriadis, “The Peoples' Democratic Party (HDP) and the 2015 Elections," Turkish Studies 17, no. 1 (2016): 40-45, https://doi.org/10.1080/14683849.2015.1136086, http://www.tandfonline.com/doi/abs/10. 1080/14683849.2015.1136086. This resulted in increased support from Turkish social democrats and liberals.
} 
country's Kurdish minority was therefore compromised by ethnic conflict and tension that allowed the framing of the HDP as marginal or even separatist political party, that could not represent interests of mainstream Turkish society.

Under such circumstances, fear-mongering became a useful instrument for the promotion of the AKP domestic political objectives. ${ }^{35}$ Highlighting the threat of economic turmoil in the event of a change of government resonated with the concerns of the Islamic, conservative middle-class whose wealth substantially improved during the AKP administration. The fear was compounded given the government's successful economic record in its first terms. Apprehension was also stoked among the AKP voter base that such a change would result in their renewed oppression, as had occurred in the years before the AKP came to power. Anxieties were also stirred with reference to Turkey's Kurds. While in the past, the AKP administration had put effort into removing the Kurdish question as a security concern per se and reframing it as a question to be solved through Turkey's democratic consolidation, its volte-face in summer 2015 led to the rekindling of concerns that the Kurdish issue could become an instrument for Turkey's partition. Indeed, officials now presented solving the Kurdish question through military means as a matter of survival (bekâ) for the Republic. Charging foreign actors with the responsibility for Turkey's domestic and foreign policy woes was not a novelty, but proved particularly handy for the AKP administration. While no conclusive evidence could be presented, suspicions that Western forces had been among the key plotters of the failed coup and had tried to use the vulnerabilities of Turkish economy as a weapon against the Turkish government were widespread in the mainstream, pro-government media and were reinforced by conspiracy theories popular in sizable segments of Turkish public opinion. The Syrian Civil War and the Kurdish question provided additional suitable frameworks. Consequently, Islamist populism appeared as a politically winning tactic. ${ }^{36}$

\section{Conclusion}

This study has explored the reasons populism has remained appealing in Greece and Turkey, particularly in light of the challenges both states have been facing over the last years. Studying how populist agendas in the two countries have thrived politically and reflected on constitutional reform

\footnotetext{
${ }^{35}$ As the new constitution concentrated all executive powers to the president, it became increasingly difficult to deflect responsibility by arguing that the executive was not in full power. The outbreak of the economic crisis in summer 2018 - reflected by the sharp fall of the exchange rate of the Turkish lira - was also attributed to foreign actors attempting to prevent the rise of Turkey into a major global actor.

${ }^{36}$ Nilüfer Göle, "Turkey Is Undergoing a Radical Shift, from Pluralism to Islamic Populism," New Perspectives Quarterly 34, no. 4 (2017): 48-49; and Bilge Yabanci, "Populism as the Problem Child of Democracy: The AKP's Enduring Appeal and the Use of Meso-level Actors," Southeast European and Black Sea Studies 16, no. 4 (2016): 595-600. This was in line with developments across the global political scene. Populism has appeared on the rise from the United States to Italy, and from Hungary to Brazil.
} 
points to the commonality of methods and the similarity of cases that would prima facie be considered incompatible. While the decision to embroider populism with left- or right-wing features remains contingent upon the intrinsic features of the political history of each country and the agency of its political leaders, the threat that both left- and right-wing populism constitute for the integrity of state institutions and the very essence of liberal democracy remains substantial and real. While right-wing populism remains a fundamental concern, it has no monopoly on threatening the foundations of liberal democracy. This also means that one needs to engage with new emerging fault lines in the political spectrum. Indeed, using a traditional leftright political dichotomy as a means of analysis may prove insufficient to explain the current configuration of European party politics. Crucial divides in European politics may be shifting from the left-to-right axis on economic and social issues to a separate axis that divides supporters of liberal democracy from those who prioritize national, class or other communitarian interests over such values. Attitudes toward individual autonomy and liberal democracy may indeed prove a more meaningful measure. Sharper analytical tools that would put populist politicians-regardless of their left- or rightwing political hue-on the same side of the political spectrum are necessary.

\section{Disclosure statement}

No potential conflict of interest was reported by the author.

\section{Funding}

The publication of this article became possible thanks to the financial support of a 2018 ASMEA research grant. Research for this article was also supported by a European Commission Education, Audiovisual and Culture Executive Agency grant [EAC-A03-2016-586489].

\section{ORCID}

Ioannis N. Grigoriadis (D) http://orcid.org/0000-0003-0882-6125

\section{Notes on contributor}

Ioannis N. Grigoriadis is Associate Professor and Jean Monnet Chair of European Studies at the Department of Political Science and Public Administration, Bilkent University. In the academic year 2018-2019, he was Visiting Professor at the Keyman Modern Turkish Studies Program, Buffett Institute for Global Studies, Northwestern University. In the academic year 2016-2017, he was Stanley J. Seeger Research Fellow at Princeton University. He has published four books and numerous academic articles. His research interests include late Ottoman and republican Turkish politics and history with a focus on nationalism and democratization. 